\title{
ANALYZING THE VARIABLES THAT INFLUENCE ACCESS TO BANK FINANCING FOR SMALL AND MEDIUM ENTERPRISES IN KOSOVO AND NORTH MACEDONIA
}

\author{
Filloreta Kunoviku-Demiri \\ Faculty of Economics, University "Isa Boletini" - Mitrovice, Kosovo \\ ORCID iD: https://orcid.org/0000-0002-8849-4417 \\ filloreta.demiri@umib.net \\ Qazim Tmava* \\ Faculty of Economics, University "Isa Boletini" - Mitrovice, Kosovo \\ ORCID iD: https://orcid.org/0000-0002-3738-8649 \\ qazim.tmava@umib.net \\ Esat A. Durguti \\ Faculty of Economics, University "Isa Boletini" - Mitrovice, Kosovo \\ ORCID iD: https://orcid.org/0000-0002-5982-3664 \\ esat.durguti@umib.net
}

\begin{abstract}
This study aims to analyze variables that influence access to bank loans by SMEs in Kosovo and North Macedonia. Research methodology is compound by primary and secondary data. We hypothesized that the age of the SMEs, business size, written business plan, collateral type, and business experience before starting as an owner, owner education, and owner gender influence access to bank loans for SMEs. Econometric model results revealed that age of the SMEs, business size, and written business plan has a significant influence on bank loans borrowed by SMEs, while, collateral type, business experience before starting as an owner, owner level of education, and owner gender have no significant influence on bank loans borrowed by SMEs in the Republic of Kosovo. Furthermore, from the results obtained we revealed that age of the SMEs, business size, written business plan, and owners' level of education has a significant influence on bank loan borrowed by SMEs, whereas, collateral type, business experience before starting as owner and owners gender have no significant influence on bank loans borrowed by SMEs in the Republic of North Macedonia. The findings suggest some future lines of research at the end and provide recommendations for the main stakeholders of this field of study.
\end{abstract}

Keywords: SMEs; Financing; Bank Loans; Growth; Comparison; Kosovo; North Macedonia 


\section{INTRODUCTION}

As developing countries, it is understandable that Kosovo and North Macedonia face a considerable number of economic problems. Around $99 \%$ of businesses in Kosovo and North Macedonia are SMEs. This percentage shows us that Small and Medium Enterprises (SMEs) development has a key role in the economic development of these countries. Bank loans are one of the main sources of external financing for SMEs in both countries and knowing that financing constraints are considered as one of the most important barriers that SMEs face, moreover, being aware of the crucial role of the SMEs in the economic development of every country, we analyzed the factors that influence the access to bank loans by SMEs.

According to studies by McKinsey and the International Finance Corporation (IFC) the total number of SMEs worldwide amounts to between 420 and 510 million. In 2013 across the EU28, some 21.6 million SMEs in the nonfinancial business sector employed 88.8 million people and generated 3,666 trillion $€$ in value-added. Expressed another way, 99 out of every 100 businesses are SMEs, as are 2 in every 3 employees and 58 cents in every euro of value-added (North and Varvakis 2016).

As mentioned above, SMEs are a key factor that impacts the economic development of every country. Their growth contributes positively to economic development, through reducing the unemployment rate, innovations, various products and services in the market, etc. Nevertheless, to grow they need financial support. Additionally, to help in this field we must determine the variables that influence access to bank loans by SMEs, in Kosovo and North Macedonia. Financing SMEs and their access to finance play a crucial role in growth and development and are key determinants of business startups. It is worth mentioning that SMEs have different needs and face different challenges concerning financing compared to large businesses (Risteska et al. 2014).

One of the biggest barriers for SMEs to grow is when they have to finance from external sources like applying for loans from Banks. In this context, The Investment Climate Survey conducted by the World Bank shows that access to finance improves firm performance. It does not only facilitate market entry, growth of companies, and risk reduction but also promotes innovation and entrepreneurial activity. Furthermore, firms with greater access to capital are more able to exploit growth and investment opportunities. In other words, aggregate economic performance will be improved by increasing access to capital (European Commission 2011). Access to finance is key to business development. Investment and innovation are not possible without adequate financing. Difficulty in getting finance is one of the main obstacles to the growth of many businesses, particularly small and medium-sized enterprises (SMEs). Financial flows to SMEs are increasing but remain subdued. Access to finance is still perceived as an important problem by several SMEs. 
Comparing different types of enterprises, micro-enterprises and more innovative businesses, in particular, consider their financing as the most pressing problem. Bank loans remain the most important source of external financing for SMEs in the EU (European Commission 2014).

The binominal business-bank relationship is critical for the growth and development of SMEs. Like in the other countries, SMEs in Kosovo and North Macedonia when they do not have enough internal funds to finance their business activities, they seek external funds, which usually are bank loans. The discussion of the relevant literature related to the access to SMEs finance, as well as to investment finance is of particular importance (Krasniqi 2004). According to Beck et al. (2007), the SMEs' access to, and cost of, finance is quite often characterized as a major difficulty, up to extent of 35 percent. It should also be stressed that the small firms come with more difficulty to loans since they encounter higher transaction costs and higher premium risks, for they are more fragile and they offer lower collaterals (Tmava 2013).

In Kosovo, bank credit is among the few external financing sources of SMEs and this is one of the reasons for the high cost of financing from banks (Grace's short period, high operational costs, huge collateral requirement up to double of the required funds for the loan, the short period of the use of financial assets even in the case of investment loans). Concerning SMEs financing, North Macedonia is in a similar position as many other emerging countries. It is completely clear that for establishing and successful functioning of a given small or medium-sized enterprise, appropriate financial sources are necessary (Risteska et al. 2014). This is exactly the reason why we chose to make research in this field, because, it is very important to identify the factors that influence access to bank loans by SMEs. In this research, we will present data from our observation that we have conducted in manufacturing and commercial (trade) oriented SMEs in the Republic of Kosovo and the Republic of North Macedonia.

To conduct this research, we have applied the data collected from primary sources, through a questionnaire with 300 respondents each in Kosovo and North Macedonia. Specifically, we will attempt to analyze the research questions as follows:

RQ1: Do the factors selected influence access to bank loans?

RQ2: Do the business plan and the type of collateral facilitate access to bank loans?

RQ3: Does the level of education and experience of business owners influence access to bank loans?

The contribution of this study is the expansion and advancement of academic literature in this field, to analyze the factors that have an impact on financing. The study also uses primary qualitative and quantitative data to conceptualize the objectives of the 
paper. Furthermore, the study addresses the issues highlighted from the perspective as follows: First, the theoretical part which will make a contribution based on data evidence and to understand in more detail the factors that affect the facilitation of approaches to finance, secondly it offers original empirical research using data for two countries applying the multiple regression model, and thirdly a perspective from the policymaking angle in terms of creating facilities to create a more favorable aspect for the development of their activities.

\section{THEORETICAL BACKGROUND}

Small and Medium Enterprises (SMEs) are considered the backbone of the economic development of every country. The growth of SMEs contributes to the economic development of both developed and developing countries. A globalized world market enables the activity of SMEs, which are becoming the driving force of economic development. Such movements led to changes in production philosophy in the most developed countries in the world during the last decades of the 20th century when the era of giant corporations was changed by an era of small enterprises, which promote the spirit of creativity and individualism, opposite to standardization and globalization promoted by the big and multinational corporations (Risteska et al. 2016).

Results from research are done in Kosovo from RIINVEST (2015) shows that access to finance is one of the top barriers for businesses expansion, and, the banks in Kosovo has the highest interest rates in the region (compared with Albania, North Macedonia, Montenegro, Serbia, and Bosnia and Herzegovina) which is a major obstacle to SMEs development. Accordingly, access to finance is a significant issue for SMEs in North Macedonia. The underdeveloped financial market, unawareness of additional sources of finance; illiquidity issues of the companies have made them susceptible to financial shocks from the domestic and the world's economy. Hence, most of the companies have used bank loans, although, they have initially suggested that commercial banks are offering banking loans with high-interest rates (Boshkoska and Lazaroski 2016). While SMEs, in general, have disadvantages in accessing finance certain types of SMEs are particularly disadvantaged, due to (1) size, such as micro-and informal enterprises, (2) age, as start-up and younger enterprises have a limited or no credit track record, less experienced entrepreneurs, limited collateral particularly in the form of fixed assets. The category of SMEs is of particular concern as these can provide a key source of output and employment growth (Harvie, Narjoko, and Oum 2015). Because financial markets are imperfect, securities buyers and sellers do not have full access to information. Individuals with available funds normally are not capable of identifying creditworthy borrowers to whom they could lend those funds. In addition, they do not have the expertise to assess the creditworthiness of potential borrowers (Madura 2018). Related to this, it is very important to elaborate on the agency theory based on 
asymmetric information. Asymmetric information is a central assumption in agency theory. Perfect information reduces the threat of opportunism as it makes it easier to detect actors' opportunistic behavior (Petersen 1993). In such an ideal situation, the principal would therefore employ a behavior-based contract and compensate the agent accordingly (Eisenhardt 1989). However, in a buyer-supplier relationship, the actors have access to different and often insufficient information about their partners' behavior. In an international supply chain, information issues are further complicated by cultural and physical distances between actors. If actors in a supply chain relationship are within a close distance, other things being equal, it would be easier (or less costly) to obtain wanted information. Similarly, the greater the distance the harder (or more expensive) it becomes to obtain wanted information (Delbufalo 2018).

Conceptual Framework

The conceptual framework of this study centered on the influence of business and owners' characteristics on SMEs' accessibility to bank loans in Kosovo and North Macedonia. The variables from this conceptual framework hypothetically were tested to establish whether there were any significant relationships between independent variables and dependent variables. The independent variables of this study are the age of the SMEs, business size, written business plan, collateral type, business experience before starting as owners, owners' level of education, and owners' gender, while, the dependent variable is bank loan borrowed by SMEs.

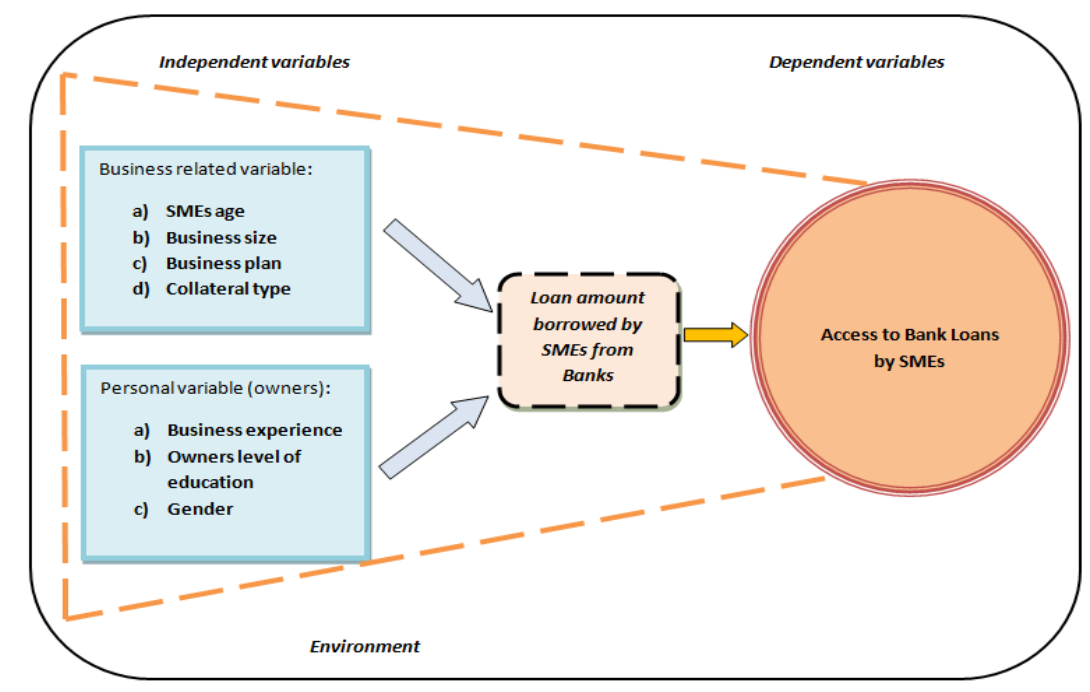

Figure 1: Conceptual Framework of Research (Source: Authors' depiction) 
Research Variables

Business and owners characteristics are among the major characteristics that can influence SMEs' accessibility to finance from banks in Kosovo and North Macedonia. Factors that we have analyzed through this study are as follows:

\section{Bank Loan}

\section{Dependent variable:}

Access to finance (bank loan) is key to business development. Investment and innovation are not possible without adequate financing. Difficulty in getting finance is one of the main obstacles to the growth of many businesses, particularly small and medium-sized enterprises (SMEs). Financial flows to SMEs are increasing but remain subdued. Access to finance is still perceived as an important problem by several SMEs. Comparing different types of enterprises, micro-enterprises and more innovative businesses, in particular, consider their financing as the most pressing problem. Bank loans remain the most important source of external financing for SMEs in the EU (European Commission 2014).

Across the globe, bank finance remains the most important source of external financing for SMEs. Many factors influence the availability of bank financing for SMEs, including the competitive environment in the banking system, the legal framework for bank lending, and the financial readiness of borrowers (OECD et al. 2020).

\section{Independent variables:}

\section{SMEs age}

While SMEs, in general, have disadvantages in accessing finance certain types of SMEs are particularly disadvantaged, due to (1) size, such as micro-and informal enterprises, (2) age, as start-up and younger enterprises have a limited or no credit track record, less experienced entrepreneurs, limited collateral particularly in the form of fixed assets. The category of SMEs is of particular concern as these can provide a key source of output and employment growth (Harwie, Narjoko, and Oum 2015). Older companies will find easier access to finance and vice versa (Beck, Kunt, Leaven, and Maksimovic 2003). This also happens in developing countries (Abor 2008). Thus, we propose the following hypothesis:

H1: The age of the SMEs influences bank loans borrowed by SMEs. 


\section{Business Size}

SMEs have generally experienced greater difficulties than their larger counterparts in accessing finance primarily due to the higher risk they represent, especially those without significant credit history or track record (BIS 2010).

There is a widely held perception that businesses - particularly small businesses face unprecedented capital access challenges. For instance, a recent study of small business capital access in North Michigan found that lack of capital was a problem for small businesses, particularly young firms, and that inadequate capital was keeping firms from growing and adding employees (Snyder et al. 2011). Beck, Demirgüç-Kunt, and Maksimovic (2005) further clarify how financial constraints affect firms of different sizes. They conclude that financial constraints affect the smallest firms most adversely and that an incremental improvement of the financial system that helps relax these constraints will be most beneficial for SMEs.

Small firms identify lack of access to financial services as one of the key constraints to growth and investment, SMEs are usually constrained than other segments of the economy because of the following: (a) financial sector policy distortions; (b) lack of know-how on the part of banks; (c) information asymmetries, for example, lack of audited financial statements; and (d) high risks inherent in lending to SMEs (Malhotra et al. 2007). Commercial banks often prefer to lend to larger enterprises, as they considered lending to small enterprises to be too risky, and their capacity to evaluate credit risks is often low (Bartlett 2008). Thus, we propose the following hypothesis:

H2: Business size influences bank loans borrowed by SMEs.

\section{Business Plan}

To get any new business idea off the ground or develop and better manage an existing business, you must have a plan and if you need to raise finance to fund the business or get the approval of senior management, it must be a convincing plan (Friend and Zehle 2009). Most business plans are prepared to secure some form of funding. In the case of new business ideas, banks, venture capitalists, private equity, and other providers of capital place great emphasis on the business plan, as this is often all they have to rely upon. To get approval or finance for a project and to help manage it is a common reason for producing a business plan. A business plan describes the business's vision and objectives as well as the strategy and tactics that will be employed to achieve them. A plan may also provide the basis for operational budgets, targets, procedures, and management control (Friend and Zehle 2009). The variable of the business plan has a significant effect on SMEs' startup bank loans and the sign of its 
coefficient is found to be positive. Theoretically, it is assumed that the business plan and SMEs' startup bank loans would be positively affected. The study has proven that a business plan can have a positive influence on SMEs' startup bank loans. Many studies have found that SMEs which have written business plans stand a higher chance of getting a bank loan (Abdesamed and Wahab 2012).

Financial characteristics like start-up capital, the current status of capital, interest rate, business plan, etc. directly affect the access to finance by SMEs (Chowdhury and Alam 2017). Thus, we propose the following hypothesis:

H3: Written business plans influence bank loans borrowed by SMEs.

\section{Collateral type}

Collateral refers to the extent to which assets are committed by borrowers to a lender as security for debt payment (Gitman 2003). The security assets should be used to recover the principal in case of default. SMEs in particular provides security in form of properties (houses, businesses, the car, and anything that could bring back the principal) in case of default on loans (Garrett 2009; Osano and Languitano 2016). Beck et al. (2006) using the World Business Environment Survey (WBES), find that collateral requirements are the third of the 12 most important financing obstacles for SMEs. Results from the EBRD and World Bank Business Environment and Enterprise Performance Survey (BEEPS) in Eastern Europe and Central Asia indicate that collateral is the fourth most important financing obstacle for external loans. Bester (1985) shows that when borrower quality is unknown, banks can use collateral as a screening device to differentiate between good and bad borrowers (Rahman et al. 2017). The study found that collateral requirements influence access to finance by SMEs in Mozambique. Most SMEs are denied and discriminated against by lenders in the provision of financing. This is because of high risk and for not having adequate resources to provide as collateral. The study also found that houses, land, and businesses are used as security and that banks demand SMEs to post the collateral to reduce moral hazard (Osano and Languitano 2016). Thus, we propose the following hypothesis:

H4: Collateral type influences bank loans borrowed by SMEs.

\section{Owners Business Experience}

Entrepreneurial skills are personal traits, experience, and human capital that favor experimentation, risk-taking, and ultimately the growth of incumbent firms (Lederman et al. 2014). Young people may suffer from negative social attitudes about their capabilities for entrepreneurship that negatively affect their self-perceptions and opportunities to 
access key resources needed in business, including financial resources, employees, and entrepreneurship-related social capital (Grilo and Irigoyen 2006). In some cases, they can be perceived as too young to be taken seriously and therefore face disapproval or lack of support from family and friends, customers, suppliers, banks, and other organizations (OECD 2013).

On the surface, it might be expected that older people will face fewer barriers in accessing external finance for business start-ups and development than younger entrepreneurs since they will tend to have greater savings, collateral, entrepreneurship skills, and business networks (OECD 2013). Senior entrepreneurs can take advantage of a wealth of knowledge, practice, learning, and experience that they have acquired through their working lives, together with an accumulated web of formal and informal workrelated networks giving access to customers, suppliers, investors, business advice, and support and other resources. However, while seniors may have acquired the technical skills needed for entrepreneurship, they have not necessarily developed business management and personal entrepreneurial skills if they spent most of their years working as employees rather than business owners, and have not worked in management (OECD 2013). Thus, we propose the following hypothesis:

H5: Owners' business experience influences bank loans borrowed by SMEs.

\section{Owners Education}

Entrepreneurs include all individuals in a position to make important strategic decisions in a firm, including managers, chief executive officers, founders, and engineers (Lederman et al. 2014). Education increases the likelihood of survival of new firms and subsequent economic performance (Acs, Armington and Zhang 2007), particularly for high-tech start-ups, where the founder's human capital is a key driver of growth (Colombo and Grilli 2010; Arvanitis and Stucki 2012; Lederman et al. 2014). Irwin and Scot (2010) based on their research, found that education plays an important role in bank's lending decisions because entrepreneurs with better education have more chances to borrow from banks. The educational level of the study participants positively influenced the likelihood of access to finance by the MSE firms at a 5 percent significant level (Tefera 2019). Thus, we propose the following hypothesis:

H6: Owners' education influences bank loans borrowed by SMEs. 


\section{Owners Gender}

The gender gap in SMEs growth is still a relatively unexplored topic, but a growing literature documents that, relative to men, women entrepreneurs are more afraid to grow their business. Empirical evidence suggests that women-owned firms tend to be smaller than firms owned by men and grow at a slower rate (GFDR 2014). Furthermore, gender-based obstacles - unconventional thinking, cultural and social values, family responsibilities, lack of management skills, and small amounts of personal capital to be used for start-ups or collateral - may aggravate the difficulties women face (OECD 2001). In the case of female entrepreneurs, the evidence, although limited, suggests that both nascent and established women entrepreneurs experience greater difficulties in financing their business ventures in comparison to their male (Henry, Johnston and Hamouda 2006). Thus, we propose the following hypothesis:

H7: Owners' gender influences bank loans borrowed by SMEs.

\section{RESEARCH METHODOLOGY}

Data and Sample

The research paradigm is quantitative. We designed a questionnaire for SMEs in Kosovo and North Macedonia which contained 25 questions that were structured in three blocks that were the general business questions, questions to identify the challenges faced by SMEs when financing through bank loans, and questions related to entrepreneurs as owners of SMEs. The target population in this research is two groups of SMEs: trading companies and manufacturing companies from all the regions in both countries Kosovo and North Macedonia, and, banks in both countries. The total population of our research is presented in the table below.

Table 1: Number of the research population (Source: Kosovo Statistics Agency; State Statistical Agency of North Macedonia)

\begin{tabular}{|l|c|c|}
\hline & Kosovo & North Macedonia \\
\hline Trading & 15,969 & 21,000 \\
\hline Manufacturing & 4,893 & 7,447 \\
\hline Total & $\mathbf{2 0 , 8 6 2}$ & $\mathbf{2 8 , 4 4 7}$ \\
\hline
\end{tabular}

To investigate the effect of independent variables and their effect on external financial access, a questionnaire was distributed to 600 businesses (300 in Kosovo and 300 in Northern Macedonia). The random method to stratification sample has been 
used, providing equal opportunities and probability to all businesses. On the stratum of the sample, the following specifics were used: active businesses, the size of the business, and the activity in which they operate, with the sole purpose of achieving the most adequate representation. Budget, time, resources, and other constraints may affect sample size considerations as well (Bartlett et al. 2001). It is often challenging for researchers to physically approach a geographically dispersed population due to limited financial resources. Traveling through different states to collect data or hiring enumerators to do so to secure an adequate and representative sample is both timeconsuming and costly (Memon et al. 2020). According to the confidence level of $95 \%$ and margin of errors 0.05 , we must say that our selected sample almost fulfills the number of SMEs that must be included in the sample size ${ }^{1}$.

In both countries, we used random samples in selecting SMEs for surveys in both sectors because of its ease of assembling the sample. It is also considered as a fair way of selecting a sample from a given population since every member is given equal opportunities of being selected. Another key feature of simple random sampling is its representativeness of the population. Data were collected in the period from June 2018 to March 2019. The research sample is explained as below:

- We realized a survey with 300 SMEs in the Republic of Kosovo.

- We realized a survey with 300 SMEs in the Republic of North Macedonia.

A research approach is a positivist approach, which means that only 'factual' knowledge gained through observation (the senses), including measurement, is trustworthy. The current study used cross-sectional data, which consisted of quantitative data, which was captured, coded and analyzed using the Statistical Package for Social Sciences (SPSS) computer software. All variables, including the response to the openended questions and closed-ended questions, were coded before being captured in SPSS (Martin and Acuna 2002).

Model Specification

There are different types of regression models, namely linear regression, logistic regression, polynomial regression, stepwise regression, ridge regression, lasso regression, and elastic net regression (O'Gorman and Maclntosh 2015). However, the type of regression model used is mostly dependent on the choice of the dependent variables. To analyze the effect of the independent variables in the dependent variable we decided to use the multiple linear regression which is used when we want to predict the value of a variable based on the value of two or more other variables.

\footnotetext{
${ }^{1}$ Research Sample Size from Research Advisers (2006).
} 
Multiple regression also allows determining the overall fit (variance explained) of the model and the relative contribution of each of the predictors to the total variance explained. Multiple linear regression attempts to model the relationship between two or more explanatory variables and a response variable by fitting a linear equation to observed data. Every value of the independent variable $x$ is associated with a value of the dependent variable $y$.

The model for multiple linear regression, given $\mathrm{n}$ observations, is:

$$
y_{i}=\beta_{0}+\beta_{1} x_{i 1}+\beta_{2} x_{i 2}+\ldots+\beta_{n} x_{n}+\varepsilon_{i} \ldots(1)
$$

Where:

- $y_{i}=$ the predicted value of the dependent variable

- $\beta_{0}=$ the $y$-intercept (value of $y$ when all other parameters are set to 0 )

- $\beta_{1} x_{11}=$ the regression coefficient $\left(B_{1}\right)$ of the first independent variable $\left(X_{1}\right)$ (a.k.a. the effect that increases the value of the independent variable has on the predicted y value)

- $\quad \ldots=$ do the same for however many independent variables you are testing

- $\beta_{\mathrm{n}} \mathrm{x}_{\mathrm{n}}=$ the regression coefficient of the last independent variable

- $\varepsilon_{\mathrm{i}}=$ model error (a.k.a. how much variation there is in our estimate of $\mathrm{y}$ )

$$
\begin{gathered}
y_{\mathrm{i}}= \\
\beta_{0}+\beta_{1} \text { Age }+\beta_{2} \text { Size }+\beta_{3} \text { Bus }_{\text {plan }}+\beta_{4} \text { Collateral }+\beta_{5} \text { Ownerr }_{\text {Experience }}+\beta_{6} \text { Ownerr }_{\text {Edu }}+ \\
\beta_{7} \text { Gender }+\varepsilon_{\mathrm{i}} \ldots \text { (2) }
\end{gathered}
$$

\section{EMPIRICAL FINDINGS}

We applied different statistical methods to analyze the data. It was run the $\mathrm{R}^{2}$ test and Anova table also to see if the model fits the data. From the results obtained we revealed that from our $\mathrm{R}$ squared value our independent variables explain $26.3 \%$ in Kosovo and $41.6 \%$ in North Macedonia of the variability of our dependent variable that is the bank loan.

Table 2: Model summary (Source: Authors' depiction)

\begin{tabular}{|l|c|c|c|c|c|c|}
\hline \multicolumn{1}{|c|}{ Model } & $\mathrm{R}$ & $\mathrm{R}^{2}$ & $\mathrm{R}^{2}$ Adjusted & $\begin{array}{c}\text { Std. the Error of the } \\
\text { Estimate }\end{array}$ & $\begin{array}{c}\text { Significance } \\
\text { F Change }\end{array}$ & Durbin-Watson \\
\hline Kosovo & $.513 \mathrm{a}$ & .263 & .223 & .636 & .000 & 1.814 \\
\hline $\begin{array}{l}\text { North } \\
\text { Macedonia }\end{array}$ & $.645 \mathrm{a}$ & .416 & .381 & .542 & .000 & 2.097 \\
\hline
\end{tabular}

a. Predictors: (Constant), If yes, what was used as collateral?, Size of the company, Owner's gender, Business experience before starting as an owner, Written business plan, Age of the SME (The year of establishment), Owner's level of education. 
To analyze the data we performed the Durbin-Watson test. The Durbin-Watson statistic tests the null hypothesis that the residuals from an ordinary least-squares regression are not autocorrelated against the alternative that the residuals follow an AR1 process. The Durbin-Watson statistic ranges in value from 0 to 4 . A value near 2 indicates non-autocorrelation; a value toward 0 indicates positive autocorrelation; a value toward 4 indicates negative autocorrelation. Because of the dependence of any computed Durbin-Watson value on the associated data matrix, exact critical values of the Durbin-Watson statistic are not tabulated for all possible cases.

Instead, Durbin and Watson established upper and lower bounds for the critical values. Typically, tabulated bounds are used to test the hypothesis of zero autocorrelation against the alternative of positive first-order autocorrelation, since positive autocorrelation is seen much more frequently in practice than negative autocorrelation. To use the table, you must cross-reference the sample size against the number of regressors, excluding the constant from the count of the number of regressors. The conventional Durbin-Watson tables are not applicable when you do not have a constant term in the regression. Instead, you must refer to an appropriate set of Durbin-Watson tables. The conventional Durbin-Watson tables are also not applicable when a lagged dependent variable appears among the regressors. From the results obtained in Kosovo, the Durbin-Watson coefficient was 1.814, whereas, in North Macedonia, was 2.097. Results revealed that there is no autocorrelation in the model used because the results are within the range of 1.5 to 2.5 .

Table 3: ANOVA (Source: Authors' depiction)

\begin{tabular}{|l|l|c|c|c|c|c|}
\hline Country & Model & $\begin{array}{c}\text { Sum of } \\
\text { Squares }\end{array}$ & df & Mean Square & $\mathrm{F}$ & Significance \\
\hline Kosovo & Regression & 18.630 & 7 & 2.661 & 6.579 & $.000^{\mathrm{b}}$ \\
& Residual & 52.187 & 129 & .405 & & \\
& Total & 70.818 & 136 & & & $.000^{\mathrm{b}}$ \\
\hline North & Regression & 24.645 & 7 & 3.521 & 11.988 & \\
Macedonia & Residual & 34.656 & 118 & .294 & & \\
& Total & 59.302 & 125 & & & \\
\hline
\end{tabular}

a. Dependent Variable: Bank Loan, b. Predictors: (Constant), Owner's gender, Size of the company, Written business plan, Age of the SMEs (The year of establishment), Collateral type, Owner's level of education, Business experience before starting as an owner.

From the results obtained we revealed that the model as a whole was significant to predict loan amount wherein Kosovo $p<.000$, whereas, in North Macedonia $p<.000$ as shown by ANOVA table results.

Furthermore, it was used a multiple linear regression model to explain the influence of independent variables in the dependent variable that in our case was a bank loan borrowed by SMEs. 
Table 4: Multiple Linear Regression Analysis (Source: Authors' depiction)

\begin{tabular}{|l|c|c|c|c|c|c|}
\hline \multirow{2}{*}{} & \multicolumn{3}{|c|}{ Kosovo } & \multicolumn{3}{c|}{ North Macedonia } \\
\cline { 2 - 7 } & $B$ & $t$ & Sig. & $B$ & $t$ & Sig. \\
\hline Constant & 1.618 & 3.615 & 0.000 & 1.733 & 5.415 & 0.000 \\
\hline Age of the SME & 0.040 & 4.016 & 0.000 & 0.011 & 3.322 & 0.001 \\
\hline Size of the company & 0.355 & 2.430 & 0.016 & 0.510 & 6.146 & 0.000 \\
\hline Written business plan & -0.188 & -2.621 & 0.010 & -0.257 & -3.368 & 0.001 \\
\hline Collateral type & 0.189 & 1.710 & 0.090 & 0.085 & 0.888 & 0.376 \\
\hline $\begin{array}{l}\text { Business experience before starting as an } \\
\text { Owner }\end{array}$ & 0.042 & 0.256 & 0.798 & 0.168 & 1.458 & 0.148 \\
\hline Owner's level of education & 0.055 & 0.577 & 0.565 & -0.189 & -2.186 & 0.031 \\
\hline Owner's gender & -0.309 & -1.692 & 0.093 & 0.111 & 0.978 & 0.330 \\
\hline
\end{tabular}

a. Dependent Variable: Bank Loan. Note. $\left(^{* *}\right),\left({ }^{* *}\right),\left(^{*}\right)$ significant, respectively, at 1,5 , and 10 percent.

From the results obtained based on the level of significance value less than .05 of each independent variable, we can argue that age of the SMEs $(P=.000)$, business size $(P=.016)$, and written business plan $(P=.010)$ have influenced significantly the bank loan borrowed by SMEs, while, collateral type, business experience before starting as an owner, owners' level of education and owners' gender has no significant influence on bank loan borrowed by SMEs in the Republic of Kosovo. Furthermore, the results revealed that in the Republic of North Macedonia age of the SMEs $(P=.001)$, business size $(P=.000)$, written business plan $(P=.001)$, and owners' level of education $(P=.031)$ have a significant influence on bank loans borrowed by SMEs, whereas, collateral type, business experience before starting as an owner and owners' gender have no significant influence on bank loans borrowed by SMEs.

\section{DISCUSSION}

Table 4 presents the results obtained from multiple linear regression, for each country included in the research. The findings in general do not have any significant differences between countries. The age of the SMEs, in both cases, has resulted in a significant influence at the level of $1 \%$, but with a moderate change in the coefficient of 4,016 , respectively 3,322 . So, in both cases, it is confirmed that the age of the SMEs has a significant positive influence on the bank loan, and these findings confirm hypothesis $\mathrm{H} 1$ in the framework of our study. The conclusion derived from these findings gives us indications that firms that exercise their activity for a longer period have easier access to finance, concerning new firms. These results agree with the studies highlighted below. Canton et al. (2013) suggest that the problem of information asymmetry discourages SMEs from credit financing, as the perception has been created that these firms do not have credible accounting records, are less transparent compared to large firms. 
In this regard, Quartey et al. (2017) in their study argue that firms that are longer in the market may have easier access to finance because they have a wider network of collaboration and a good history created with financial institutions. Also, the variable size of the company, which is considered critical in treating this phenomenon, based on empirical findings has resulted in having a significant impact at the level of $1 \%$. The findings for this variable confirm the verification of hypothesis $\mathrm{H} 2$, where it is argued that the size of the company has a significant influence on the creation of access to finance. The findings for the hypothesis $\mathrm{H} 2$ size of the company are consistent with the findings of Brixiova et al. (2020), where they analyzed 42 sub-African countries, using an assessment-based approach to access to finance, and arguing that businesses that have easier inflow to bank finance have better opportunities in job creation than SMEs that do not have inflow to financing.

The drafting of a business plan, which is a guiding map of business growth on the one hand, and the requirements set by the regulatory authority of financial institutions, which obliges commercial banks to set as a criterion when applying for a loan, is a very important component for facilitating access to bank loans. Therefore, the generated econometric results show that the drafting of the business plan has an important effect of $1 \%$, in Kosovo, respectively, in North Macedonia. The coefficient of this effect is negative, which proves that SMEs without business plans can be rejected when applying for bank loans. Based on these outcomes, hypothesis H3 is confirmed, that the drafting of the business plan has a mitigating effect on the financing approach. The results for this component so far have appeared mixed, our results are in full agreement with the studies conducted by Zahra and Garvis (2000) where they argue that these variables have important correlations. Whereas, they are in contradiction with the results of Durguti et al. (2020) where they argue that in the case of Kosovo the drafting of the business plan has an insignificant effect.

Based on the results revealed we argue that hypothesis $\mathrm{H} 4$ we can't confirm. Based on these results where the level of significance is higher than $.05, \mathrm{H} 4$ turns out not to be confirmed in the case of Kosovo at the level of significance of $10 \%$, while in the case of North Macedonia it turned out to be non-significant as the P-value is 0.376 , and in this case, it is confirmed that the type of collateral hasn't significant influence on facilitating access to finance. The outcome turns out to be surprising and at the same time challenging, as globally, and according to the criteria of the Basel Committee, it is recommended to banks to apply the security measures for non-failure of loans by borrowers, which is considered a secondary mechanism of the fulfillment of the obligation. This finding is not consistent with the findings of Mullei and Bokea (2000) who argue that banks require collateral to finance SMEs and that the collateral must be at least $100 \%$ or more equal to the loan extension amount or the financing product. The same findings have been reached by Osano and Languitone (2016) were their findings on the factors that influence access to finance, the demand for collateral has turned out 
to be significant. Additionally, hypothesis $\mathrm{H} 5$, business experience before starting as an owner has turned out to be of insignificant impact. Our findings are in line with the findings of Ogubazghi and Muturi (2014) which argue that the educational level of the owner/manager does not have a significant effect on access to the bank loan.

The level of education of the owners is undoubtedly an important component to analyze what impact it has on the development of the firm on the one hand, as well as in the context of presenting the $\mathrm{H} 6$ hypothesis on the other hand. The results reflected in Table 4, concerning this variable ensures that the level of education has a nonsignificant impact as the P-value is 0.565 in the case of Kosovo, while with a significant impact of $1 \%$, it turned out to be within the case of North Macedonia, as the P-value is 0.031 . In most studies conducted so far, the level of education of owners/managers is classified into primary, secondary, and tertiary education. Zarook et al. (2013); Slavec and Prodan (2012) have found that the level of education of owners impacts facilitating access to finance. Moreover, Pandula (2011) has also found that educational background has a significant impact on access to bank loans.

The owner's gender is a variable that has received special attention in the last decade in the Western Balkans. The reason is that the loan financing of businesses owned by women has been linked to the provision of collateral, which has significantly improved the issue but has also advanced in the policy-making process. Therefore, in hypothesis H7, we can't confirm, wherein the case of Kosovo and in North Macedonia, it turned out to be non-significant. Calcagnini et al. (2015) in their study 'Gender Differences in Bank Loan Access: An Empirical Analysis' argue that traditionally female business owners have difficulty or high costs in accessing bank credit. Additionally, their results did not show a significant impact, which is in line with the results of our study.

\section{CONCLUSION}

This research aimed to analyze the influence of factors, age of the SMEs, business size, written business plan, collateral type, and business experience before starting as an owner, owners' level of education, and owners' gender in SMEs' access to bank loans. As explained earlier the sample is composed of manufacturing and commercial SMEs that operate in the Republic of Kosovo and Republic of North Macedonia conducted with executives of 300 SMEs in Kosovo and 300 SMEs in North Macedonia during 2018-2019. Using data from a self-administered survey gives us the possibility to analyze some of the factors that are important for access to bank loans by SMEs. Moreover, it is important to mention that there are no other studies in this field that are based on comparative analysis between Kosovo and North Macedonia.

From the results obtained we conclude that the age of the SMEs has a positive influence on access to bank loans borrowed by SMEs in Kosovo and North Macedonia. The conclusion derived from these findings gives us indications that firms that exercise 
their activity for a longer period have easier access to finance, concerning new firms. Furthermore, from the results obtained we conclude that business size influences positively the access to finance by SMEs in Kosovo and North Macedonia which means that smaller firms have harder access to finance than larger firms.

Regarding the business plan, we conclude that a written business plan has a negative influence on access to bank loans by SMEs which proves that SMEs without business plans can be rejected when applying for bank loans. Moreover, the owner's level of education has a significant influence on access to bank loans for SMEs in the Republic of North Macedonia.

From our data analyses, we conclude that collateral type, business experience before starting as an owner, and owners' gender have no significant influence on access to bank loans by SMEs in Kosovo and North Macedonia.

Our recommendations for policymakers are: to develop programs for financial support of the SMEs; to develop special programs for financial support of the manufacture SMEs because they will impact positively in the trade balance through exports; to develop special funds through which will provide support for the payment of interest rates of the SMEs loans; to develop special programs for financial support of the women entrepreneurs; to establish policies that will influence in the raise of banking competition, and, will provide: improvement on the financing conditions for SMEs, lower interest rates and other banking expenses, higher grays period, facilitation of the collateral requirements, higher repayment deadlines for SMEs. Furthermore, for SMEs in both countries that finance their business through bank loans, we recommend analyzing the factors that influence access to finance which we identified through our findings to facilitate their access to bank loans.

For this stage of research, we have selected only a few independent variables to analyze how they influence the access to bank loans by SMEs. Moreover, we are aware that other variables might influence access to finance. Furthermore, this opens some lines for future researches. Therefore, future studies should consider analyzing other variables that might influence SMEs' access to bank loans. 


\section{REFERENCES}

1. Abdesamed, H. \& Wahab, K. (2012). Do experience, Education, and Business plan influence SMEs start-up Bank loan? The Case of Libya. Australian Journal of Basic and Applied Sciences, 6, 234-239.

2. Abor, J. (2008). Determinants of the Capital Structure of Ghanaian Firms. The African Economic Research Consortium.

3. Acs, Z., Armington, C. \& Zhang, T. (2007). The determinants of new-firm survival across regional economies: The role of human capital stock and knowledge spillover. Papers in Regional Science. DOI:10.1111/j.1435-5957.2007.00129.x.

4. Arvanitis, S. \& Stucki, T. (2012). How Swiss Small- and Medium-Sized Firms Assess the Performance Impact of Mergers and Acquisitions. Small Business Economics. DOI:10.2139/ssrn.2150136.

5. Bartlett, W. (2008). Europe's Troubled Region: Economic development, institutional reform and social welfare in Western Balkans. Routledge. DOl:10.4324/9780203644898.

6. Bartlett, W., Bateman, M., \& Vehovec, M. (2002). Small Enterprise Development in southeast Europe: Policies for sustainable growth. Springer Science+Business Media, LLC. DOI 10.1007/978-1-4615-0959-2.

7. Bartlett, J. E., Kotrlik, J. W. \& Higgins, C. C. (2001). Organizational Research: Determining Appropriate Sample Size in Survey Research.

8. Beck, Th., Demirgüç-Kunt, A. \& Levine, R. (2006). Bank Concentration, Competition, and Crises: First results. World Bank.

9. Beck, Th., Demirgüç-Kunt, A. \&Maksimovic, V. (2005). Financial and Legal Constraints to Growth: Does Firm Size Matter?. The Journal of Finance.

10. Beck, Thorsten; Demirguc-Kunt, Asli; Maksimovic, Vojislav. (2003). Financial and Legal Institutions and Firm Size. Policy Research Working Paper; No. 2997. World Bank, Washington, DC. (C) World Bank. https://openknowledge.worldbank.org/handle/10986/19157

11. Besanko, D. and Thakor, A. (1987). Competitive Equilibrium in the Credit Market under Asymmetric Information. Journal of Economic Theory, 42, 167-182. http://dx.doi.org/10.1016/0022-0531(87)90108-6.

12. Bester, H. (1985). Screening vs. Rationing in Credit Markets with Imperfect Information. The American Economic Review. https://www.jstor.org/stable/1821362

13. BIS (2010). Financing a private sector recovery.

14. Boshkoska, M., \& Lazaroski, S. (2016). Access to Finance of the Macedonian Companies in the Post-Crisis period. TEM Journal, 353-362. DOI: 10.18421/TEM53-16. 
15. Calcagnini, G., Giombini, G. \&Lenti, E. (2015). Gender Differences in Bank Loan Access: An Empirical Analysis. Ital Econ J 1, 193-217 (2015).

https://doi.org/10.1007/s40797-014-0004-1.

16. Canton, E., Grilo, I., Monteagudo, J., \& van der Zwan, P. (2013). Perceived credit constraints in the European Union. Small Business Economics, 41(3), 701-715. https://doi.org/10.1007/s11187-012-9451-y.

17. Delbufalo, E. (2018). Agency Theory and Sustainability in the Global Supply Chain. Springer. DOI:10.1007/978-3-319-72793-6 3.

18. Chan, Y. and Kanatas, G. (1985) Asymmetric Valuation and the Role of Collateral in Loan Agreements. Journal of Money, Credit and Banking, 17, 84-95. http://dx.doi.org/10.2307/1992508.

19. Chowdhury, M., \& Alam, Z. (2017). Factors Affecting Access to Finance of Small and Medium Enterprises (SMEs) of Bangladesh. USV Annals of Economics and Public Administration, 2 (26), 55-68. Retrieved from https://touroscholar.touro.edu/gsb_pubs/12

20. Dlabay, L. R., \& Burrow, J. L. (2008). Business Finance. Thomson.

21. De Bruin, A. \& Firkin, P. (2001). Self-Employment of the Older Worker. Labour Market Dynamics Research Programme.

22. Deakins, D., and Hussain, G. (1994), "Risk Assessment with Asymmetric Information", International Journal of Bank Marketing, Vol. 12 No. 1, pp. 2431. https://doi.org/10.1108/02652329410049571.

23. Durguti, E., Krasniqi, E., \&Krasniqi, D. (2020). The impact of manager's experiences in entrepreneurship evidence from Kosovo SME's. JurnalPerspektifPembiayaan Dan Pembangunan Daerah, 8(2), 175 - 184. https://doi.org/10.22437/ppd.v8i2.9447.

24. EUC (2014). Survey on the access to finance of enterprises (SAFE). European Central Bank. DOI:10.2873/435315.

25. Fisher, E., \& Reuber, R. (2000). Industrial Clusters and SME Promotion in Developing Countries. Commonwealth Secretariat.

26. Friend, G., \& Zehle, S. (2009). Guide to Business Planning. Wiley.

27. Global Financial Development Report. (2014). Financial Inclusion. The World Bank.

28. Harvie, C., Narjoko, D., \&Oum, S. (2015). Economic Integration in East Asia: Production networks and small and medium enterprises. Routledge.

29. Henry, C., Johnston, K., \&Hamouda, A. (2006). Access to finance for women entrepreneurs in Ireland: A supply-side perspective.

30. Lederman, D., Messina, J., Pienknagura, S., \&Rigolini, J. (2014). Latin American Entrepreneurs: Many firms but little innovation. The World Bank.

31. Levy, B., Berry, A., \& Nugent, J. B. (1999). Fulfilling the Export Potential of Small and Medium Firms. Springer Science+Business Media, LLC.

32. Madura, J. (2018). Financial Markets and Institutions. Cengage Learning. 
33. Malhotra, M., Chen, Y., Criscuolo, A., Fan, Q., Hamel, I. I., \& Savchenko, Y. (2007). Expanding Access to Finance: Good practices and policies for micro, small and medium enterprises. Washington D.C.: World Bank.

34. Martin, K. \& Acuna, C. (2002). SPSS for Institutional Researchers. Bucknell Lewisburg, Pennsylvania: University Press.

35. Memon Ali, M., Ting, H., Hwa J. Ch., \&Ramayah, T. (2020). Sample Size for Research: Review and Recommendations. Journal of applied structural equation modeling. DOI:10.47263/JASEM.4(2)01

36. Mullei, A., \& Bokea, A. (2000). Micro and small enterprises in Kenya: agenda for improving the policy environment. Nairobi: I.C.E.G.

37. North, K., \& Varvakis, G. (2016). Competitive Strategies for Small and Medium Enterprises. Springer.

38. O'Gorman, K.D. \& Maclntosh, R. (2015) "Chapter 4 Mapping Research Methods" In O\&apos; Gorman, K.D. \& Maclntosh, R. (ed). Oxford: Goodfellow Publishers http://dx.doi.org/10.23912/978-1-910158-51-7-2772.

39. OECD. (2001). Women entrepreneurs in SMEs. OECD.

40. OECD. (2013). The Missing Entrepreneurs: Policies for Inclusive Entrepreneurship in Europe. OECD Publishing.

41. OECD et al. (2020), SME Policy Index: Eastern Partner Countries 2020: Assessing the Implementation of the Small Business Act for Europe, SME Policy Index, OECD Publishing, Paris/European Union, Brussels, https://doi.org/10.1787/8b45614b-en.

42. Ogubazghi, S. K., \& Muturi, W. (2014). The Effect of Age and Educational Level of Owner/Managers on SMMEs' Access to Bank Loan in Eritrea: Evidence from Asmara City. American Journal of Industrial and Business Management, 632-643. DOI:10.4236/ajibm.2014.411069.

43. Osano, H., \& Languitano, H. (2016). Factors influencing access to finance by SMEs in Mozambique: the case of SMEs in Maputo central business district. Journal of Innovation and Entrepreneurship. https://doi.org/10.1186/s13731-016-0041-0.

44. Pandula, G. (2011) An Empirical Investigation of Small and Medium Enterprises Access to Bank Finance: The Case of an Emerging Economy. ASBBS Annual Conference, Proceedings of ASBBS, Las Vegas, 18, 255-273.

45. Quartey, P., Turkson, E., Abor, J. Y., \& Iddrisu, A. M. (2017). Financing the growth of SMEs in Africa: What are the constraints to SME financing within ECOWAS? Review of Development Finance, 7(1), 18-28. https://doi.org/10.1016/j.rdf.2017.03.001.

46. Rahman, A., Belas, J., Kliestik, T., \& Tyll, L. (2017). Collateral Requirements for SME Loans: Empirical evidence from the Visegrad Countries. Journal of Business Economics and Management, 650-675. https://doi.org:10.3846/16111699.2017.1357050. 
47. Read, L. (2002). The Financing of Small Business: A comparative study of male and female business owners. Routledge.

48. Risteska, A., Nikoloski, D., Gveroski, M., Spaseska, T., \& Risteska, F. (2014). Analysis of SMEs Financing in the Republic of Macedonia - Conditions and Perspectives. Annals of the "Cons tantinBrâncuşi" University of Târgu Jiu, Economy Series, 9-16.

49. Risteska-Jankulloska, A., Sotiroski, K., Gveroski, M., Spaseska, T., \&Risteska, F. (2016). SMEs and Innovation: Case of Macedonia. Annals of the "Constantin Brâncuşi" University of Târgu Jiu, Economy Series, 141-151.

50. Slavec, Alenka \& Prodan, Igor (2012). "The influence of entrepreneur's characteristics on small manufacturing firm debt financing," Journal of East European Management Studies, Rainer Hampp Verlag, vol. 17(1), pages 104-130.

51. Snyder, J. et.al. (2011). Understanding Small Business Needs and Capital Access Barriers in Northern Lower Michigan. Michigan State University.

52. Tefera, K. T. (2019). Determinants of Access to Finance for Micro and Small-Scale Enterprises in Nekemte Town. Research Journal of Finance and Accounting, 3446. DOI: 10.7176/RJFA/10-19-04.

53. Tmava, Q., Peci, F., \& Luboteni, G. (2013). The Role of Banks in Small and Medium Enterprises Financing: A case study from Kosovo. International Journal of Economics and Finance, 94-103.DOl:10.5539/ijef.v5n12p94

54. Zahra, S.A., Ireland, R.D. \& Hitt, M.A. (2000). International expansion by new venture firms: International diversity, mode of market entry, technological learning, and performance. The Academy of Management Journal, 43(5), 925-950 https://doi.org/10.5465/1556420.

55. Zarook, T., Rahman, M.M. and Khanam, R. (2013) Management Skills and Accessing to Finance: Evidence from Libya's SMEs. International Journal of Business and Social Science, 4, 106-115. DOI: 10.4236/ajibm.2014.411069.

56. Zuzana Brixiová, Thierry Kangoye, Thierry UrbainYogo, (2020). Access to finance among small and medium-sized enterprises and job creation in Africa, Structural Change and Economic Dynamics, Volume 55,2020, Pages 177-189, ISSN 0954349X, https://doi.org/10.1016/j.strueco.2020.08.008. 